\title{
The Environmental and Population Health Benefits of Active Transport: A Review
}

\author{
Richard Larouche \\ Children's Hospital of Eastern Ontario \\ Canada
}

\section{Introduction}

In 2007, the prestigious medical journal The Lancet published a series of papers entitled Energy and Health. In his commentary, Richard Horton argued that "The current debate about the impact of human beings on our planet - especially with respect to climate change - is one of the most important issues of our time. But that debate is presently unbalanced and too narrow." He considered that the relationship between energy and health had been clearly neglected by governments and international institutions such as the World Health Organization and the World Bank. One of the proposed pathways to reduce our global footprint while improving our health is to switch from an automobile-dependent transportation system to a lowcarbon system characterized by an increased utilization of modes of transportation such as walking, cycling and public transport (Horton, 2007; Woodcock et al., 2007).

On a worldwide basis, transport activities account for $23 \%$ of $\mathrm{CO}_{2}$ emissions and this proportion is steadily increasing (International Transport Forum, 2010). Moreover, worldwide $\mathrm{CO}_{2}$ emissions from transport have increased by $45 \%$ from 1990 to 2007 (International Transport Forum, 2010). In parallel with their rapid economic growth, transport-related $\mathrm{CO}_{2}$ emissions are increasing markedly in developing countries such as China and India (Woodcock et al., 2007). For example, in China, total motorized travel distance has increased almost five-folds between 1980 and 2003 (Zhou \& Szyliowicz, 2006).

Within the transport sector, private vehicles represent the second most important contributor to greenhouse gases (GHG) emissions behind road freight (Chapman, 2007). Existing road infrastructure cannot cope with the rapid increase in the number of vehicles; thereby generating traffic jams which, aside from the increased GHG emissions, have dire economic consequences. For example, Levy et al. (2010) estimated that fuel wasted and time lost in traffic jams in 83 American cities cost 60 billion US\$. Moreover, they evaluated that mortality associated with ambient exposure to fine particulate matter $\left(\mathrm{PM}_{2.5}\right)$ cost an additional 31 billion US\$ in these cities. Although technological innovations may contribute to reduce the intensity of $\mathrm{CO}_{2}$ emissions from transport in a long term perspective, more immediate changes in transport behaviors are crucial to achieve a stabilization of the absolute emissions in order to mitigate climate change (Chapman, 2007).

Data from the 1995 Nationwide Personal Transportation Survey in the US indicate that private cars were used for about $90 \%$ of trips of 0.5 to 3 miles, of which an important 
proportion could be substituted by walking, cycling and public transport (de Nazelle et al., 2010). This would represent an interesting strategy to reduce GHG emissions considering the disproportionate contribution of short trips to pollutant emissions due notably to cold starts (Frank et al., 2000). Further, since most individuals must travel to work or to school on a daily basis, active transport (e.g. using active modes of transportation such as walking and cycling) is increasingly regarded as a promising alternative to increase physical activity (PA) levels (Larouche \& Trudeau, 2010; Shephard, 2008).

From a public health perspective, there is clear evidence of a strong relationship between PA and several health-related illnesses including cardiovascular diseases (Manson et al., 2002), diabetes (Sigal et al., 2006), cancer (Friedenreich \& Orenstein, 2002), and all-cause mortality (Paffenbarger et al., 1993). Moreover, the prevalence of obesity has increased throughout the world to such an extent that it is now considered a pandemic (Lobstein et al., 2004; Wang \& Lobstein, 2006). Recent research has also shown that the majority of the population fails to accumulate enough daily PA (Colley et al 2011a, b; Troiano et al., 2008). During the last decades, the rates of AT to/from school in children and adolescents has decreased markedly in several countries (Buliung et al, 2009, Grize et al., 2010; McDonald, 2007; van der Ploeg et al., 2008). Further, exposure to ambient air pollution is associated with respiratory and cardiovascular morbidity and mortality (Brook et al., 2010; Brunekreef \& Holgate, 2002).

To implement more effective strategies to promote active transport (AT), it is necessary to develop a greater understanding of the factors associated with individuals' mode of transport, that is the correlates of AT 1 . Current theoretical models suggest that the choice of travel mode is based on several factors including characteristics of the individual (i.e. perceived barriers to active transport), of the social environment (i.e. social support), of public policies (i.e. laws and taxes) and of the built environment (i.e. population density and land-use mix) (Panter et al., 2008; Sallis et al., 2006). These models are typically based on the social ecological theory (i.e. Bronfenbrenner, 1979) which predicts that human behavior result from the interactions within and between these multiple "levels of influence".

Consequently, the current review is organized in four main sections. First, the impact of various transportation strategies to reduce emissions of GHG and other pollutants are described. Second, the impacts of AT on physical activity, physical fitness and other healthrelated outcomes are summarized. Third the correlates of AT are briefly examined to identify key variables to consider for the promotion of AT as a strategy to reduce GHG emissions and increase physical activity. Finally, the fourth section examines the interrelationships between the environmental and public health impacts of AT.

\section{Methods}

Potentially relevant articles were identified through databases including Medline, PsychInfo, Google Scholar and the National Transportation Library. Keywords such as "active transport", "active commuting", "active travel" were used in addition to the following exposures or outcomes: "greenhouse gas", "carbon dioxide", "climate change",

\footnotetext{
${ }^{1}$ As detailed in the current review, most of the research that has examined the factors associated with AT have used a cross-sectional methodology. Therefore, the term "correlates" is used rather than the term "determinants" which involves a causal relationship (Bauman et al., 2002).
} 
"traffic", "physical activity", "physical fitness", "obes", “overweight", "diabetes", "cardiovascular disease", "cancer", "hypertension", "all-cause mortality", "correlates", "determinants". Other articles were added from the author's personal library. In addition, reference lists of previous reviews were scanned to identify potentially relevant literature.

Articles were selected on the basis that they provide additional elements to the comprehension of the explored phenomena. To be included in the review, articles generally needed to have examined AT, either as an outcome variable or as an exposure. However, in some cases, studies that examined the association between environments recognized as conductive to AT were also considered eligible. There were no restriction with respect to date of publication; however, most included studies were published during the last 10 years. Studies published in English or French were considered eligible.

For the section on the impact of transport practices on pollution and GHG, priority was given to the natural experiments in which the impact of transport policies was rigorously examined before and after the intervention. To complement this rather scarce literature, simulations and cross-sectional studies were also included. For the section on the healthrelated outcomes of AT, priority was given to the studies that used an experimental design, which provide the highest level of evidence. These studies were complemented by prospective cohort studies, large cross-sectional studies and systematic reviews. Finally, as a systematic examination of the correlates of AT was beyond the scope of this book chapter, a simplified ecological model was used to categorize the most important factors into five levels of influence, as illustrated in Figure 1.

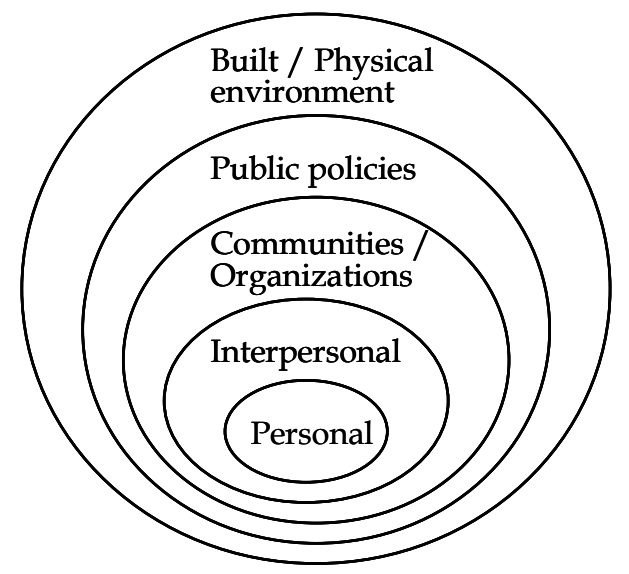

Fig. 1. Simplified ecological model for categorizing the correlates of active transport into the different levels of influence.

\section{Impact of transport practices on pollution and greenhouse gases}

\subsection{Natural experiments}

In central London, a congestion charging scheme was introduced by the mayor in February 2003. Drivers are charged $£ 8$ (about US\$16) to enter the downtown core during working hours. While the scheme had little impact on the concentrations of $\mathrm{CO}_{2}$ and $\mathrm{PM}_{10}$ in Greater 
London, small decreases were observed in the central wards. Estimated years of life gained were 183 per 100000 individuals. Interestingly, air pollution and mortality reductions were greater in more deprived areas, but emissions nevertheless remained higher in these areas compared to the more affluent areas (Tonne et al., 2008). A similar scheme was implemented in Stockholm and it resulted in a 15\% decrease in vehicle miles travelled accompanied by 8.5-14\% reductions of the emissions of nitric oxides, $\mathrm{PM}_{10}$ and $\mathrm{CO}_{2}$ in the inner city (Johansson et al., 2009). However, as in London, changes in emissions were lower in the Greater Stockholm (1-3\%), suggesting that the impact of congestion charging schemes is mostly localized.

For the 1996 Summer Olympic Games in Atlanta, a transportation strategy was developed to minimize traffic congestion and to ensure that spectators could commute to the Olympic events in a reasonable amount of time. This strategy included the development of a public transportation system operating 24 hours a day, the addition of 1000 buses for park-and-ride services, the closure of the downtown core to private automobile travel, and modified delivery schedules (Friedman et al., 2001). Local businesses were also encouraged to implement alternative work schedules. Using an ecological study design, Friedman and colleagues (2001) examined the impact of these changes in traffic on air quality and childhood asthma events. They observed a $22.5 \%$ reduction in weekday peak traffic that was correlated $(\mathrm{r}=0.36)$ with a $27.9 \%$ reduction in ozone concentration. Reductions in concentrations of carbon monoxide, $\mathrm{PM}_{10}$ and nitrogen dioxide were also noted. Lower rates of childhood asthma acute care events were also reported.

Similarly, a combination of aggressive measures was put in place in order to improve air quality for the 2008 Beijing Olympic Games. Private vehicles with odd-numbered license plates were allowed to circulate on Beijing's roads one day and those with even numbers were allowed on the next day, while vehicles that failed to meet the European No. 1 standard for exhaust emissions were banned. Power plants and large factories were also required to reduce their emissions (Wang et al., 2009). These measures have led to reductions in the concentration of sulfur oxide, carbon monoxide, nitric oxides and ozone of $61 \%, 25 \%, 21 \%$ and $26 \%$ respectively. It is however unclear whether such policies could be implemented at a larger scale and for longer periods of time.

\subsection{Simulations}

Woodcock and colleagues (2009) examined the impact of different transportation scenarios on carbon emissions and public health for the year 2030. Using the cities of London and Delhi as examples, they modeled the impact of five scenarios: 1) Business as usual; 2) Lower carbon-emission motor vehicles; 3) Increased active travel; 4) "Towards sustainable transport (e.g. a combination of scenarios 2 and 3); and 5) Increased active travel, but shorter distances travelled. In London, the scenario \#1 would lead to a $4 \%$ increase in $\mathrm{CO}_{2}$ emissions from 1990 levels while scenarios 2 to 5 would lead to 35-60\% reductions of emissions. In Delhi, due to the projected increases in population and in the level of motorization, the predicted $\mathrm{CO}_{2}$ emissions from all scenarios would represent major increases in comparison with 1990 levels. However, with scenario \#4, the increase would be 199\% compared to 526\% for the business as usual scenario. The "Towards sustainable transport" scenario would have the greatest impact on mortality in London (7 439 disability-adjusted life-years) and Delhi (12 995 disability-adjusted life-years). Increasing the mode share of AT would have a greater impact than relying on technology (e.g. lower-emissions motor vehicles). 
Similarly, American researchers examined the impact of five different education policy scenarios on vehicle emissions during children's school commuting in St-Paul, Minnesota using data from a school travel survey and a school enrollment data set (Marshall et al., 2010). In the first scenario, children where modeled as attending the school that they actually attended. The second scenario randomly assigned children to any school in the district. In the third scenario, children were assigned to the closest school in their neighborhood. In the fourth scenario, the district was subdivided into three regions and most children were assigned to a school in the district where they lived. Finally, the fifth scenario is similar to the first one, except that all children living within 1 mile of school were modeled as active commuters. Emissions of $\mathrm{CO}_{2}, \mathrm{CO}, \mathrm{NO}_{\mathrm{x}}, \mathrm{PM}_{10}$ and volatile organic compounds were predicted using the US Environmental Protection Agency's MOBILE6 model ${ }^{2}$. The third scenario would be the most effective, achieving 3- to 8-fold reductions in the pollutant emissions with a 7 -fold reduction in transport costs. Further, because only $27 \%$ of children lived within 1 mile of their actual school, this scenario would achieve an even greater mode share of AT. However, this scenario would go against the habit of free choice; thus, it would likely be a challenge to gather public acceptability.

Using data from the 1995 Nationwide Personal Transportation Survey, de Nazelle et al. (2010) estimated the impact of conversing short car trips (defined as $<3$ miles) to alternative modes of transportation on pollutant emissions. Their estimates suggest that, across the US, daily emissions reductions would amount to 30-70 tons for volatile organic compounds, 1535 tons for nitrogen oxides, and 400-900 tons for carbon monoxide. Daily reductions in GHG emissions would vary between 20000 to 46000 tons of $\mathrm{CO}_{2}$ equivalent. This simulation is based on a very small decrease in vehicle miles travelled $(0.8 \%$ to $1.8 \%)$, while it is estimated for example that a $10 \%$ increase in the price of gas can reduce consumption by $2.5 \%$ (Kaza et al., 2011). Thus, one could argue that there is a potential for greater reductions of driving.

\subsection{Observational studies}

Combining data from the Neighborhood Quality of Life Study and the King County Land Use, Transportation, Air Quality, and Health Study, Frank and colleagues (2006) examined the interactions between land use, pollution and health. Their analyses indicate that a $5 \%$ increase in the index of walkability ${ }^{3}$ was associated with decreases in vehicle miles travelled (6.5\%), $\mathrm{NO}_{\mathrm{x}}$ emissions (5.6\%) and volatile organic compounds (5.5\%). Such an increase in walkability was also associated with lower body mass indices $\left(-0.228 \mathrm{~kg} / \mathrm{m}^{2}\right)$ and with $32.1 \%$ more minutes of weekly AT. Similar analyses based on the SMARTRAQ study in the Atlanta area have shown that increased residential density, street connectivity and transit accessibility were associated with increased walking and decreased driving (Frank et al., 2010). In contrast, increasing the land-use mix was associated with reductions in both driving and walking, probably because individuals travel shorter distances in this type of environment (Frank et al., 2010).

Further, a study from the US Environmental Protection Agency (1999) compared the impact of new residences in already built-up areas (e.g. infill development) vs. new residences built

\footnotetext{
2 This model can be found at www.epa.gov/otaq/mobile.htm

${ }^{3}$ Walkability refers to the ability to walk to certain destinations within the neighborhood. This concept is further described in section 5.1 of this book chapter.
} 
in the suburbs and exurbs (e.g. greenfield development) in San Diego (CA), Montgomery County (MD) and West Palm Beach (FL). In the denser "infill" developments, vehicle miles travelled were $40-50 \%$ lower, emissions of $\mathrm{CO}_{2}$ and $\mathrm{NO}_{x}$ were about $50 \%$ lower and public infrastructure costs were also markedly lower.

However, the concentrations of $\mathrm{NO}_{x}$ can nevertheless be higher in more "walkable" areas, which are characterized by higher population density and land-use mix (Marshall et al., 2009), emphasizing the need to distinguish emissions and concentrations. For example, in Vancouver (Canada), a strong correlation was noted between neighborhoods walkability and $\mathrm{NO}_{\mathrm{x}}$ concentrations. High walkability areas were mostly located in the more densely populated city center through which residents of the suburbs are likely to commute to work. However, ozone is a secondary pollutant formed in the atmosphere rather than emitted directly from traffic exhaust, so high concentrations generally occur downwind from the high density areas; hence ozone concentrations in Vancouver where higher in the suburbs (Marshall et al., 2009).

Altogether, these studies suggest that the design of more walkable neighborhoods could lead to a decrease in the mode share of driving that should, in turn, lead to reductions of GHG emissions. However, because these studies have used a cross-sectional design, their findings must be interpreted with caution. There may be an underlying self-selection issue such that individuals choose to live in a neighborhood that meets certain preferences (Frank et al., 2007). To address this issue, Handy and colleagues (2005) compared the travel behaviors of residents who had moved during a 1-year period to others that did not while controlling for neighborhood preferences. They found that changes in neighborhood characteristics were associated with changes in walking and driving. In their model, accessibility of destinations was the strongest predictor of changes in driving, emphasizing the importance of land-use mix.

Another study explored the relationship between urban form and the ecological footprint associated with commuting patterns in the 163 municipalities of the Barcelona metropolitan region, Spain (Muniz \& Galindo, 2005). Between 1986 and 1996, per capita ecological footprint increased by $95 \%$ driven by increases in the average trip distance (from $4.6 \mathrm{~km}$ to $6.7 \mathrm{~km}$ ), and the mode share of car trips (22 to $35 \%$ ). The mean trip distance and the ecological footprint of commuting increased systematically as distance from the city center increased reflecting higher car use. In addition, population density and accessibility of destination were negatively associated with ecological footprint.

\section{Health-related outcomes of active transport}

\subsection{Controlled trials}

A recent systematic review identified 2 randomized controlled trials in which individuals were randomly assigned either to an AT or a passive transport (PT) group (Oja et al., 2011). Specifically, in the first study, 68 Finnish adults who were classified as insufficiently active before the study were assigned either to a PT or an AT (walking or cycling) group. Individuals from the latter group were asked to engage in AT to work on every workday for 10 consecutive weeks (Oja et al., 1991). Participants accumulated an average of 1 hour of daily AT. Cardiovascular fitness $\left(\mathrm{VO}_{2} \mathrm{max}\right)$ increased by $4.5 \%$ in the AT group, while cycling led to a greater improvement than walking ( $7 \%$ vs. $2 \%)$. Statistically significant 
improvements were also noted for HDL cholesterol, blood lactate concentration during exercise and cardiovascular endurance in the AT group (Oja et al., 1991). In the second randomized controlled trial, 122 Dutch adults were assigned either to a PT or a cycling group for a 6 months period (Hendriksen et al., 2000). Maximal power output increased by $13 \%$ in both men and women, and $\mathrm{VO}_{2}$ max increased by $6 \%$ in men while, in the PT group, $\mathrm{VO}_{2}$ max decreased by $5-10 \%$. In addition, despite no changes in body mass, there was a reduction in the percentage of body fat in the cycling group (Hendriksen et al., 2000).

In a Belgian non-randomized controlled trial, 65 middle-aged men and women were asked to cycle to work at least three times a week for a one year period, while the 15 participants from the control group were asked not to change their travel patterns (de Geus et al., 2009). Participants from the experimental group cycled 2.5 days per week for 45 minutes per day. Their maximal power output increased by $5 \%$, but their $\mathrm{VO}_{2}$ max decreased by $1 \%$, while corresponding figures in control participants were $2 \%$ and $-7 \%$. Albeit small, differences between groups were significant for both maximal power output and $\mathrm{VO}_{2} \mathrm{max}$, and individuals who cycled the most had greater improvements in fitness. As hypothesized by Oja et al. (2011), the smaller effect observed in this study compared to the 2 randomized controlled trials could be explained by lower cycling frequency and lower daily cycling time.

\subsection{Prospective studies}

Andersen and colleagues (2000) assessed the relationship between cycling to work and allcause mortality among a cohort of 6954 Danish adults. The relative risk of mortality was 0.72 (95\% CI 0.57-0.91) among the cyclists, even after adjusting for physical activity, cholesterol and triglyceride levels, body mass index, blood pressure, education level, smoking status, gender, and age at the beginning of the study. Similarly, a prospective study of 75221 women aged 40-70 from seven communities in Shanghai has shown lower rates of all-cause mortality after 5.7 years of follow-up. The relative risk of mortality was 0.66 (95\% CI 0.40-1.07) among the women who cycled the most when adjusted for a similar range of potential confounders (Matthews et al., 2007).

Gordon-Larsen and colleagues (2009) examined the prospective impact of AT to work on body composition, cardiovascular disease risk factors and cardiovascular fitness among 2364 participants from the Coronary Artery Risk Development in Young Adults that were followed for 20 years. When controlling for age, race, income, education, smoking, examination center and physical activity index, men who used AT to work had a reduced risk of obesity $(\mathrm{OR}=0.50 ; 95 \% \mathrm{CI}=0.33-0.76)$, lower triglyceride levels $(\mathrm{OR}=0.88 ; 99 \% \mathrm{CI}=$ $0.80-0.98)$, fasting insulin ( $\mathrm{OR}=0.86 ; 95 \% \mathrm{CI}=0.78-0.93)$ and diastolic blood pressure (OR $=$ $-1.67 ; 95 \% \mathrm{CI}=-3.20 ;-0.15)$. Furthermore, both men and women who used AT had greater cardiovascular fitness as measured by time to exhaustion on a treadmill test.

$\mathrm{Hu}$ and colleagues (2005) prospectively followed a cohort of 47721 Finnish adults aged 2564 and without history of coronary heart disease, stroke or cancer at baseline. They found that compared to participants who did not used AT, those who used AT for 1-29 minutes per day $(\mathrm{RR}=0.92 ; 95 \% \mathrm{CI}=0.84-1.01)$ and those who engaged in 30 minutes of more of daily AT $(\mathrm{RR}=0.89 ; 95 \% \mathrm{CI}=0.80-0.98)$ were less likely to have suffered a stroke during the 19 years of follow-up. In the same cohort, AT to work was also associated with a reduced risk of coronary heart disease in women, but not in men (Hu et al., 2007). 
Using a prospective case-control study design, Wennberg et al. (2010) found that car commuting was associated with a markedly increased risk of myocardial infarction $(\mathrm{OR}=$ $1.77 ; 95 \% \mathrm{CI}=1.05-2.99$ ), even when adjusting for smoking, education level, leisure time physical activity, occupational physical activity, hypertension and diabetes. The effect of AT was partly mediated by variables such as BMI, the ratio of apolipoprotein B/apolipoprotein A-1 and other inflammatory and hemostatic biomarkers.

In line with these findings, a meta-analysis of prospective epidemiological studies has indicated that individuals who use AT have an 11\% lower risk of cardiovascular events including mortality, coronary heart disease, stroke, hypertension and diabetes (Hamer \& Chida, 2008). However, differences were more pronounced in women $(\mathrm{RR}=0.87 ; 95 \% \mathrm{CI}=$ $0.77-0.98)$ than in men ( $R R=0.91 ; 95 \% C I=0.80-1.04)$ and direct comparison of studies is complicated by the inclusion of different endpoints.

Wen and Rissel (2008) examined the association between different modes of transport to work and the risk of overweight and obesity in a representative sample of 6810 Australian adults. The prevalence of overweight $(39.8 \%$ vs. $60.8 \%$; OR $=0.49 ; 95 \%$ CI $0.31-0.76)$ and obesity ( $5.4 \%$ vs. $15.5 \%$; OR $=0.34 ; 95 \% \mathrm{CI}=0.13-0.87$ ) was significantly lower among men who cycled to work. No such differences were seen in women, of whom only $0.33 \%$ cycled to work. There were also no difference between individuals who walked to work and those who drove.

Among children, data from the 322 children that participated to the 6-year follow-up of the Danish arm of the European Youth Heart Study indicated a positive relationship between cycling to school and cardiovascular fitness (Cooper et al., 2008). Children who cycled at both time points and those who changed from non-cycling to cycling had a $9 \%$ greater maximal aerobic power than those who did not cycle at any time point and those who stopped cycling. However, no difference in BMI was observed in this study, and children who walked to school did not have greater fitness than those who were driven. A more recent analysis of the same dataset revealed longitudinal associations between cycling to school and lower waist circumference, serum glucose and insulin (Andersen et al., 2011). Cyclists were less resistant to insulin according to the homeostasis model assessment (e.g. HOMA), and their ratio of HDL to total cholesterol was also lower. Differences in other risk factors were not significant, but overall, the clustered risk of cardiovascular disease was markedly lower among cyclists.

\subsection{Cross-sectional studies and literature reviews}

Pucher and colleagues (2010) assessed whether the mode share of AST was associated with the prevalence of obesity and diabetes and with the proportion of individuals meeting the PA guidelines in 14 different countries, all 50 states in the US, and 47 of the 50 largest American cities. They found large negative correlations $(r=-0.45$ to -0.8$)$ between the mode share of AT and obesity rates at the country, state and city levels. They also found that the prevalence of diabetes was markedly lower and that more individuals were sufficiently active in cities and states with higher mode share of AT.

Using data from the Montréal Origin-Destination survey, Morency and Demers (2009) determined the number of trips of less than $1 \mathrm{~km}$ made by children aged 5-14 $(\mathrm{N}=16837)$ and estimated the number of steps per day that these trips would involve if they were 
substituted by walking. Their findings indicate that $31.2 \%$ of the daily trips were $<1 \mathrm{~km}$ and that $33.0 \%$ of these trips were motorized. Overall, these trips would require an average of 2238 steps per child, which translates into $16.6 \%$ of the recommended volume of daily physical activity.

Faulkner and colleagues' (2009) systematic review has shown that AT to and from school was associated with a higher level of objectively measured physical activity level among children and adolescents in 11 out of 13 studies. A more recent systematic review has evaluated the associations between AT to and from school, PA, body composition and cardiovascular fitness (Larouche et al., submitted). Currently, 78\% of studies have shown that active commuters accumulate significantly more daily PA than passive commuters. A dose-response relationship such that active commuters who lived further away from school accumulated more PA than those who lived closer has been found in two of the reviewed studies (Panter et al., 2011; van Sluijs et al., 2009).

However, there remains inconclusive evidence regarding the association between AT to and from school and body composition outcomes (Larouche et al., submitted). This is not very surprising because body weight regulation is a very complex phenomenon (Jéquier \& Tappy, 1999; Keith et al., 2006) and even the evidence on the association between overall physical activity levels and body weight remains conflicting (Harris et al., 2009). Further, the energy expenditure associated with AT can be compensated by changes in other energybalance related behaviors during the day (i.e. by eating more or by spending more time in sedentary behaviors). However, all reviewed studies have shown that cycling was associated with greater physical fitness, while associations were less consistent for walking or AT in general (e.g. combined walking and cycling) (Larouche et al., submitted).

\section{Correlates of active transportation}

Despite the potential of AT to reduce GHG emissions while improving many indicators of public health, the proportion of individuals using active modes of transportation remains very low in several countries. While several initiatives have been implemented to promote utilitarian walking and cycling, few of these have been evaluated rigorously. Systematic reviews of interventions to promote walking and cycling as an alternative to driving have indicated modest positive changes (Ogilvie et al., 2004; Yang et al., 2010). Furthermore, few studies have sought to determine the factors associated with changes in travel mode (Hume et al., 2009; Owen et al., 2004).

Altogether, these limitations in current knowledge highlight the importance of examining more carefully the correlates of AT. While a detailed review of the correlates of AT is beyond the scope of this book, a brief description of the main correlates is provided for five different levels of influence according to the ecological model: the built and physical environment ${ }^{4}$, public policies, communities and organizations, interpersonal factors, and personal factors.

\footnotetext{
${ }^{4}$ The built environment refers to "the physical features of the urban landscape (i.e. alterations to the natural landscape) that collectively define the public realm, which might be as modest as a sidewalk or an in-neighborhood retail shop or as large as a new town." (Cervero \& Kockelman, 1997).
} 


\subsection{Built and physical environment correlates}

Several reviews highlight strong associations between elements of the built environment, the mode share of active transport and the number of vehicle miles travelled (Larouche \& Trudeau, 2010; Saelens \& Handy, 2008; Sallis et al., 2006). The term "walkability" is often used by urban planners and researchers to refer to the ability to walk to certain destinations within the neighborhood (Sallis et al., 2006). The 3D model proposed by Cervero and Kockelman (1997) is a central component in most indices of walkability (Sallis et al., 2006). The three components of this model are: 1) Density (e.g. the amount of individuals or households within a given area); 2) Diversity (often referred to as land-use mix or the variety of destination within a given area); and 3) Design (which includes various attributes such as street connectivity, sidewalks and cycling infrastructure, aesthetics, etc.).

There is consistent evidence supporting the associations between density and land-use mix with adults' travel mode (Ewing et al., 2003; Frank et al., 2006; Saelens \& Handy, 2008). Pooling data from the 206992 adult participants to the 1998, 1999 and 2000 Behavioral Risk Factor Surveillance System, Ewing et al. (2003) assessed the relationship between urban sprawl and physical activity, obesity and morbidity in 448 counties and 83 metropolitan areas in the US. The county sprawl index was positively associated to body mass index and hypertension, and negatively associated with time spent walking. Another American study reported that individual who lived in neighborhoods characterized by high walkability accumulated 70 more minutes of weekly PA than those who lived in less walkable neighborhoods (Saelens et al., 2003). However, studies that examined the impact of design on travel mode have found conflicting results (Saelens \& Handy, 2008; Sallis et al., 2006). Another caveat of the walkability construct is neighborhood self-selection; i.e. active individuals may decide to live in walkable areas (Handy et al., 2006).

Amongst children and adolescents, a systematic review of 14 studies which measured environmental correlates of AT to/from school with geographic information systems has shown that distance was the only consistent correlate (Wong et al., 2011). There was conflicting evidence regarding the impact of density and diversity, suggesting that these constructs may not be as relevant as for adults. The mode share of AT to/from school also tends to be lower in secondary schools students who generally need to travel greater distances (Pabayo et al., 2008, 2011).

\subsection{Public policies}

Differences between countries in the mode share of cycling are particularly striking. For example, the proportion of trips made by bicycle varies from about $1 \%$ in countries such as USA, UK, Australia and Canada to 18\% in Denmark and 27\% in the Netherlands (Pucher \& Buehler, 2008). Further the mode shares of cycling for distances $<2.5 \mathrm{~km}, 2.5-4.4 \mathrm{~km}$ and $4.5-$ $6.4 \mathrm{~km}$ in the Netherlands are respectively $37 \%, 37 \%$ and $24 \%$, while corresponding figures in the US are $2 \%, 1 \%$ and $0.4 \%$. These large variations can be partly explained by differences between countries in factors such as the provision of cycling infrastructure, the quality of public transit networks, gas prices and other expenses associated with car ownership, and urban planning practices (Banister, 2008; Chapman, 2007).

From an historical perspective, the industrial revolution has led to a major increase in the population of cities and infectious diseases spread rapidly in overcrowded neighborhoods 
in which individuals were exposed to high concentrations of coal and other pollutants (Frumkin et al., 2004). To address this public health issue, urban planning policies were implemented to segregate factories from households. Nevertheless, urban areas of the early $20^{\text {th }}$ century were still generally favorable to AT: density was moderate to high, land-use mix was the norm and streets were built in a grid-like fashion which facilitates navigation. Then, after World War II, urban planning policies primarily focused on car-oriented development which has led to increasing urban sprawl and decreasing density, land-use mix and street connectivity. Hence, Turcotte (2008) reported that newer homes where located further away from the city center based on findings from the 2006 Canadian census. This type of development has led to major reductions in the mode share of AT (Frumkin et al., 2004; King et al., 2002).

In contrast, to address the environmental and public health issues associated with caroriented development, Northern European countries adopted a series of policies to promote AT and reduce car travel in the middle of the 1970s, as described by Pucher and Buehler (2008). These policies have led to 20-43\% increases in the mode share of AST in cities such as Amsterdam and Groningen (Netherlands), Copenhagen and Odense (Denmark) and Berlin and Muenster (Germany), and large reductions in the relative risk of traffic injuries were observed.

\subsection{Communities and organizations}

Local communities can promote AT through different strategies, including the provision of walking and cycling infrastructure (Dill \& Carr, 2003; Pucher et al., 2010), bike-sharing schemes (DeMaio, 2009), parking restrictions (Pucher \& Buehler, 2008) and Safe Routes to School and/or walking school buses schemes (Heelan et al., 2009; Hinckson \& Badland, 2011). Moreover, Giles-Corti (2006) argues that the inclusive or exclusive nature of the social environment fosters the social norm that may increase or decrease the likelihood of PA in general or AT specifically - and that car-oriented development favors social exclusion. It has also been proposed that increasing social cohesion could lead to more "eyes on the street" (Jacobs, 1961), which could favor children's independent mobility and AT.

Workplaces can also play a role in the promotion of AT. For example, a workplace-based social marketing campaign in a large Finnish factory ( $\mathrm{N}=1256$ employees) achieved a $7 \%$ increase in the proportion of workers using AT (Oja et al., 1998). Australian researchers examined the influence of workplaces on travel mode among 888 adults (Wen et al., 2010). Respondents whose workplace encouraged AT were significantly less likely to drive to work than those without such encouragement ( $49 \%$ vs. $73 \%$; OR $=0.41 ; 95 \% \mathrm{CI}=0.23-0.73$ ). In contrast, participants who had access to convenient parking near their workplace were almost 5 times more likely to drive. In Belgium, a similar survey revealed that individuals who reported that their workplace offered safe bicycle parking spots and showers were more likely to cycle to work (de Geus et al., 2008).

\subsection{Interpersonal factors}

According to Bandura's (1986) social cognitive theory, human behavior is strongly influenced by modeling and by social interactions with significant others. In support of this theory, researchers have found that individuals whose friends and/or family members 
engaged in AT were more likely to walk or cycle for utilitarian purposes (de Geus et al., 2007; Titze et al., 2007). Similarly, social support has been shown to be positively related to AT (Ball et al., 2007; Titze et al., 2008).

In addition, current theoretical frameworks assume that parents are the key decision makers for their children's mode of transportation to school (McMillan, 2005; Panter et al., 2008). To further explore this decision making process, Faulkner et al. (2010) conducted semistructured interviews with 37 parents. Their findings suggest that, after deciding if their children needed to be escorted, parents typically chose the mode of transport that they perceived to be the quickest and most convenient. Other studies have shown that parental concerns about road safety are inversely related with children's likelihood of walking or cycling to school (Davison et al., 2008; Panter et al., 2008).

\subsection{Personal factors}

Several studies have shown that men were more likely than women to use AT and this gender difference tends to be much greater for cycling (Bell et al., 2006; Davison et al., 2008; Garrard et al., 2008). Interestingly, in countries with higher mode shares of cycling, no gender differences were observed whereas in Australia, US, UK and Canada, less than 30\% of bike trips are made by women (Pucher \& Buehler, 2008). Australian researchers suggested that this situation may reflect higher risk aversion among women; underscoring the importance of developing safe cycling infrastructure to promote commuter cycling among women (Garrard et al., 2008). Perceptions of lack of time (Oja et al., 1998; Shannon et al., 2006), car ownership (Ogilvie et al., 2008; Wen et al., 2010), road safety concerns (Garrard et al., 2008; Panter et al., 2008; Titze et al., 2007) and hilly routes (Troped et al., 2003) have also been associated with lower rates of AT. While weather conditions are often cited as a barrier to AT (Humpel et al., 2004), it is noteworthy that the Scandinavian countries all have cycling mode shares above $10 \%$, while cycling is much less common in Mediterranean countries, US and Australia (Pucher \& Buehler, 2008).

In contrast, studies have consistently shown a positive association between self-efficacy perceptions and AT (Ball et al., 2007; de Geus et al., 2008; Sallis et al., 2006; Troped et al., 2003). Other personal factors that may favor AT include the desire to be physically active or to increase fitness (Oja et al., 1998; Shannon et al., 2006; Titze et al., 2007), intentions and habits to walk or cycle (Lemieux \& Godin, 2009), and environment-friendly attitudes (Bopp et al., 2011; de Geus et al., 2008).

\section{The nexus between the environment and public health}

As highlighted by McMichael and Butler (2011), there is currently a paradox between the increasing disruptions of the global environments (i.e. rising GHG emissions, oversized ecological footprint, acidification of the oceans, destruction of stratospheric ozone, degradation of arable land, depletion of freshwater supplies, loss of biodiversity, etc.) and the improvement in indices of population health (especially life expectancy). They further explain: "The factors that have historically underpinned population health gains are now, by dint of their much increased scale, scope, and intensity undermining sustainable good health as we exceed Earth's capacity to renew, replenish, provide and restore" (McMichael and Butler, 2011). Hence, profound changes in lifestyle will likely be required to avoid widespread societal collapse, 
like it has happened several times in history, albeit at a much smaller scale (Weiss \& Bradley, 2001).

As the transport sector is currently one of the most important contributors of climate change (Unger et al., 2010) while PT represents a significant health risk, it is fair to consider that transport practices represent a major nexus between the environment and public health. In other words, interventions promoting AT as a source of physical activity also have important environmental implications and, inversely, GHG emissions policies aiming to reduce car use would have major public health implications.

One factor that may play a determinant role with respect to both GHG emissions and indicators of public health is the likely occurrence of "peak oil" which is defined as "the maximum rate of the production of oil in any area under consideration, recognizing that it is a finite natural resource subject to depletion" 5 While some authors perceive peak oil as a great opportunity to promote healthier modes of transport (Demers, 2008; Frumkin et al., 2004; Younger et al., 2008), others are less optimistic (Hanlon \& McCartney, 2008; Kaza et al., 2011). Nevertheless, the impacts of peak oil are difficult to forecast given the uncertainty associated with its occurrence, its impact on gas price, the rapidly increasing oil demand from developing countries, the availability of alternative fuels and their actual impact on pollutant emissions, the public policies that will be implemented by different countries, etc.

The gas embargo of the 1970s show that countries can use different strategies in order to adapt to the rising price of gas (Mapes, 2009). In the US, sales of bicycles literally doubled in the 2 years following the embargo, but once gas prices dropped, bicycle sales plummeted, and the mode share of cycling remained very low thereafter. In contrast, this crisis made Dutch policy makers realize that they did not have control over their gas supplies so, after the embargo was over, they maintained high fuel taxes and invested massively in the development of infrastructure for alternative modes of transportation (Mapes, 2009).

Another insightful example in this regard is the fuel shortage experienced during Cuba's "special period" following the collapse of the Soviet Union in the early 1990s (Franco et al., 2008) which has led to a major increase in the mode share of AT. The proportion of physically active individuals increased from 30 to $67 \%$, while the prevalence of obesity declined from 14 to $7 \%$ and large reductions in mortality from diabetes $(-51 \%)$, coronary heart disease $(-35 \%)$, stroke $(-20 \%)$ and all-cause mortality $(-18 \%)$ were observed. However, a neuropathy outbreak affected 50000 individuals in 1992-1993, but its impact amongst children, pregnant women and the elderly was minimized by a special rationing system. These historical examples suggest that different countries will implement different strategies in response to peak oil, and these strategies may have markedly different environmental and public health impacts.

\subsection{The case for health impact assessment studies}

Health impact assessment studies represent a promising strategy to simultaneously assess the environmental and health-related impacts of AT policies and interventions (de Nazelle et al., 2011). As illustrated in Figure 2, a comprehensive framework has been proposed to integrate the impact of policies/interventions on: 1) the behavioral changes (including

\footnotetext{
${ }^{5}$ For more details, see: http://www.peakoil.net/about-peak-oil
} 
changes in modes of transport); 2) the environment (i.e. air pollution, greenhouse gases); and 3 ) the health risks and benefits resulting from the interaction between behavioral changes and environmental exposures. It is anticipated that such an approach could allow researchers and policy-makers to examine if a given intervention can achieve improvements in the health status of individuals while providing environmental co-benefits.

However, only a few such assessments have been conducted to date (de Nazelle et al., 2011). First, Dutch researchers simulated the impact on all-cause mortality if 500000 individuals would switch from car travel to cycling for short trips on a daily basis (de Hartog et al., 2010). Their findings indicate that the benefits from increased PA (3-14 months gained) would be much greater than the mortality resulting from greater doses of inhaled air pollution (0.8-40 days lost) and the potential increase in traffic accidents (5-9 days lost). Furthermore, such a change in mode of transportation would result in air quality improvements that would benefit the whole population.

A second health impact assessment study was conducted for the Bicing bike-sharing scheme in Barcelona, Spain which was implemented in 2007 as a strategy to reduce traffic congestion (Rojas-Rueda et al., 2011). By August 2009, 182062 residents had subscribed (about 11\% of the population), of which 28251 were considered regular users (Rojas-Rueda et al., 2011). It was estimated that the Bicing initiative led to an annual reduction of 9062344 $\mathrm{kg}$ of $\mathrm{CO}_{2}$. The health impact assessment predicts that Bicing would cause 0.16 deaths/year because of traffic accidents and inhalation of air pollution, but it would prevent 12.46 deaths/year due to increased physical activity (benefit-risk ratio $=77$ ). Considering that bike-sharing schemes have been implemented in several cities in Europe, Asia and North America (DeMaio, 2009), these initiatives could have positive impacts both for population health and climate change mitigation.

The findings of these health impact assessment studies are coherent with the "safety in number" principle which suggests that a mode of transport becomes safer as more people use it (Jacobsen, 2003; Tin Tin et al., 2011). This principle also has its corollary: when less people use a mode of transport, it tends to become more dangerous. In this regard, the number of cycling injuries has increased while per capita time spent cycling decreased during the last decade in New Zealand (Tin Tin et al., 2011).

Jacobsen's (2003) power law model predicts that, if a community was to double its mode share of AT, the relative risk of injury for each walker or cyclist would drop to 0.66 . At the community level, the rate of injury would increase by $32 \%$ for a $100 \%$ increase in the mode share of AT. It is noteworthy that the relationship between the mode share of AT and rates of injuries is non-linear and tends to vary between communities. Furthermore, Elvik (2009) argued that due to the non-linearity of risk, very large transfers of trips from motorized modes to AT could lead to a reduction in the absolute number of reported accidents.

Among children and adolescents, various schemes such as "Safe Routes to School" and walking school buses have been implemented to promote AT while reducing the risk of injuries (Davison et al., 2008). In the mid-1970s, Denmark had the highest child pedestrian accident rate in Europe (Appleyard, 2003). To address this issue, the city of Odense invested in the creation of an extensive network of pedestrian and bicycle paths, narrowed roads, added traffic islands, and mandated all of its 45 schools to identify specific road-safety issues. After ten years, child pedestrian and cyclist casualties had decreased by $80 \%$ and this 
program was implemented at the national level. Moreover, studies have repetitively shown that more than $60 \%$ of Danish adolescents cycle to school (Andersen et al., 2011). School travel planning was also very successful in the UK where pedestrian and cyclist casualties felt by $77 \%$ and $28 \%$ respectively (Appleyard, 2003).

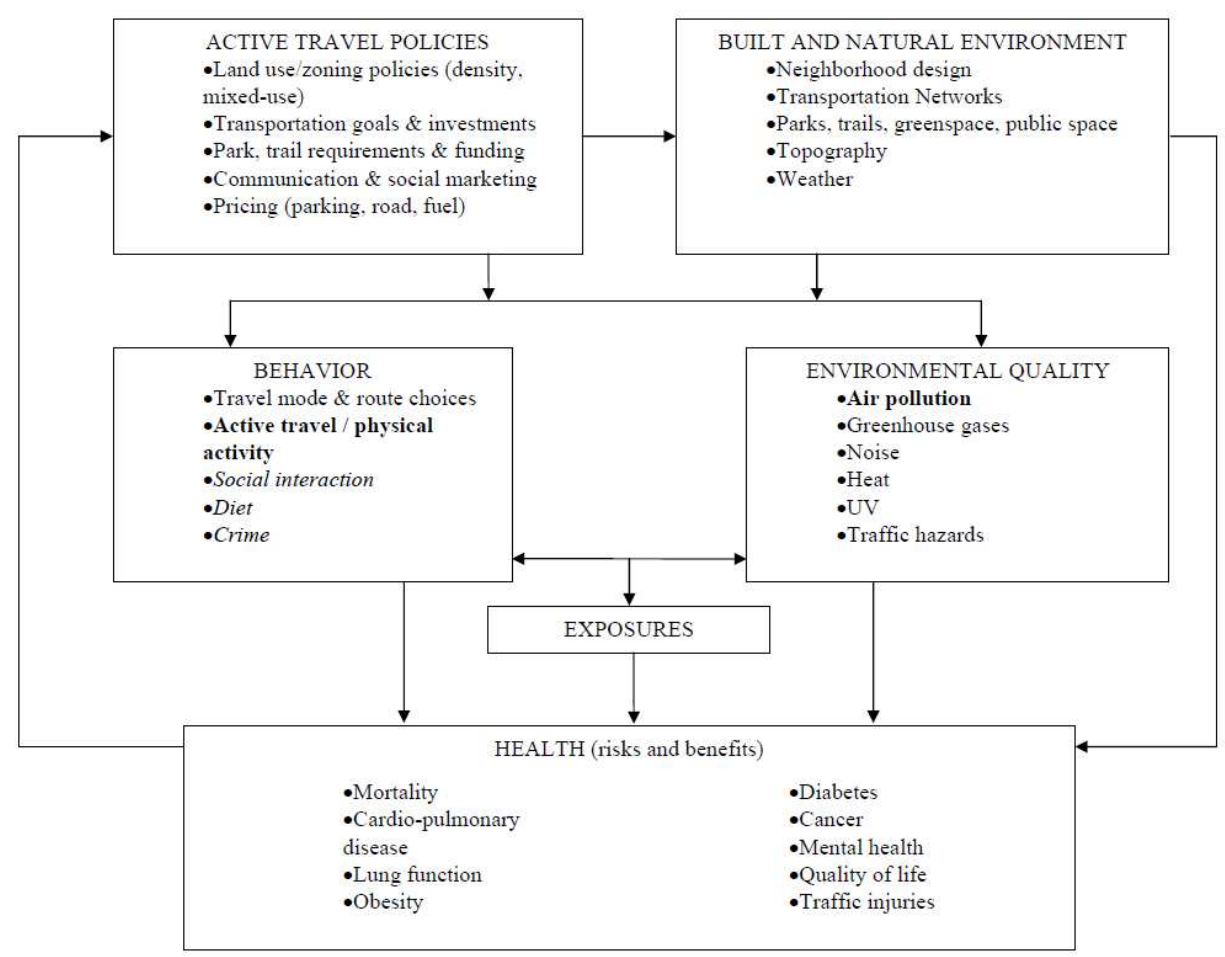

Fig. 2. Conceptual model of health impacts of active travel policies. In bold are shown behavioral and environmental quality variables recognized as having strongest exposurehealth quantifications available, while variables in italics are the most uncertain to quantify. (Reproduced with permission from de Nazelle et al., 2011).

A recent systematic review of interventions promoting AT to school reported that most were effective in increasing the mode share of AT and/or decreasing driving (Chillón et al., 2011). However, the majority of these studies reported small effect sizes and most did not assess the broader impacts of the interventions on environmental and health-related outcomes.

These studies provide preliminary evidence to suggest that a transition from PT to AT could have rather positive environmental and health impacts. The magnitude of these impacts will likely depend on the degree of behavior change. For example, larger reduction in driving would achieve greater reductions in exhaust emissions and could decrease walkers' and cyclists' risk of accident to a greater extent. However, further studies will need to take into account socio-economic status because individuals living in deprived neighborhoods are typically exposed to higher concentration of pollutants (Marshall et al., 2009; Tonne et al., 
2008). Moreover, low income households and families with young children are likely to be more affected by a potential increase in the cost of food transportation caused by fuel scarcity (Kaza et al., 2011).

\section{Limitation and strengths of present review}

Overall, this review is limited by the lack of prospective intervention studies that examined the impact of policies aimed at reducing greenhouse gases emissions. In the absence of such studies, simulations provide an interesting alternative to examine the impact of large-scale changes in transportation practices. However, simulations are limited by their reliance on highly uncertain assumptions about factors such as the potential for behavioral change, the occurrence of peak oil, the confounding variables not accounted for, and the magnitude of technological innovations.

While there has been a lot of studies on the correlates of AT, few of these have rigorously examined the factors associated with changes in travel mode. This may partly explain the modest success of interventions that sought to increase the mode share of AT. The findings of the current review nevertheless suggest that more comprehensive interventions tend to be more effective, highlighting the need for better integrated policies to promote AT and reduce the mode share of $\mathrm{PT}$.

In addition the use of the social-ecological approach for the description of the correlates of AT can be perceived both as a strength and as a limitation. This model allows the consideration of a wide range of factors located at different levels of influence emphasizing the interactions between different variables (McLeroy et al., 1988; Sallis et al., 2006). However, ecological models can be criticized for being too complicated; rendering the identification of intervention targets more difficult (Stokols, 1996).

The main strength of the current review is the broadness of its scope which allowed a simultaneous examination of both the environmental and the public health impacts of AT. Further, this review summarizes the increasing evidence supporting the positive association between AT and several indicators of public health including increased PA and physical fitness, and decreased morbidity and all-cause mortality. This body of evidence should therefore be useful for policy-makers to justify investments to promote AT by the perspective of combined environmental and public health benefits. Haines et al. (2010) argue that such policies should be more cost-effective and socially attractive than strategies addressing climate change or public health separately.

\section{Conclusion}

The share of the global $\mathrm{CO}_{2}$ emissions attributable to the transport sector is increasing steadily while the level of motorization is rising rapidly in developing countries (International Transport Forum, 2010). In this context, the present review sought to examine the impact of transportation strategies to reduce emissions of GHG and other pollutants. Few studies have used a rigorous experimental or natural experiment design and current investigations assessed localized interventions (i.e. the congestion schemes in central London and Stockholm) or exceptional measures taken for reducing traffic congestion during the Olympic Games in Atlanta and Beijing. However, simulations and observational 
studies provide preliminary evidence suggesting that transport policies could achieve considerable reductions in GHG emissions.

The second objective of this chapter was to summarize the literature on the health benefits of AT. Altogether, the reviewed studies suggest that increasing the mode share of AT may lead to multiple health benefits (i.e. declines in the risk of obesity, cardiovascular diseases, diabetes, hypertension, cancer, etc.). The benefits vary across studies, but importantly, all available health impact assessment studies have concluded that the benefits of increasing the mode share of AT largely outweighed the risks (de Hartog et al., 2010; de Nazelle et al., 2011; Rojas-Rueda et al., 2011). Moreover, controlled trials have consistently shown that commuter cycling led to improved cardiovascular fitness. The findings from another randomized controlled trial suggest that lifestyle-oriented physical activity (such as AT) can result in greater compliance than structured physical activity programs (Dunn et al., 1999).

Despite this wide range of potential benefits, the mode share of AT is exceedingly low in most industrialised countries except The Netherlands, Germany and the Scandinavian countries. This highlights the necessity of developing a better understanding of the correlates of AT in order to increase the effectiveness of interventions to promote AT.

Current models that predict the choice of travel mode (i.e. Panter et al., 2008; Sallis et al., 2006) are rooted in the social ecological theory. Based on this theory, intervening only by trying to convince individuals to change their transport behaviors would likely be effective only among individuals who are highly receptive to this message (i.e. those who have a high degree of concerns about environmental issues). In this context, Banister (2008) argues that a paradigm shift from the "conventional approach" to transport planning (or car-oriented development) towards a sustainable mobility paradigm (or people-oriented development) is urgently needed. However, to achieve such a paradigm shift, it is necessary to gain public acceptability in order to drive social and political action (Banister, 2008).

The example of Northern European countries suggests that it is feasible to achieve public acceptability. Furthermore, the cities that had the most success in increasing the mode share of AT are those that implemented comprehensive multi-level strategies (Pucher et al., 2008, 2010). Such strategies can include a combination of incentives to individuals who adopt active transportation (i.e. tax credits), an increased availability of sidewalks, cycle paths, improved public transport systems, an increased community/organizational support for active transportation (i.e. provision of safe places to store bicycles, showers in workplaces), traffic calming strategies, policies to increase the cost of car use (e.g. increased fuel taxes or reduced availability of car parking), and well-designed social marketing campaigns (Oja \& Vuori, 2000; Pucher et al., 2010).

As noted in the 'limitations and strengths' section, there is a clear need for more prospective intervention studies in order to increase the overall quality of evidence. In this regard, future studies should: 1) assess in a more comprehensive fashion the effectiveness of AT interventions and their impact on environmental variables (including GHG emissions) and health-related outcomes; and 2) identify key variables associated with changes in travel modes to inform the design of more effective interventions.

Although stronger proof of effectiveness from experimental studies and natural experiments would increase the quality of evidence and may potentially increase public acceptability, it 
should not be viewed as a reason to maintain car-oriented development. First, large increases of motorization in developing countries such as China and India, coupled with the status quo in developed countries are expected to lead to major increases in GHG emissions (Woodcock et al., 2007, 2009). The transport sector already accounts for $23 \%$ of worldwide $\mathrm{CO}_{2}$ emissions. Second, exposure to vehicle exhaust gases is strongly associated with cardiovascular morbidity and mortality (Brook et al., 2010). Third, there is already strong evidence supporting that commuter cycling leads to significant increases in cardiovascular fitness, which is an important cardiovascular disease risk factor (Oja et al., 2011). Fourth, due to the safety in number principle, an increase in the mode share of AT typically leads to a decrease in the relative risk of traffic injury for each commuter (Jacobsen, 2003).

Further, there are economic reasons supporting a shift to the sustainable mobility paradigm. First, Stern's (2006) review illustrated that if we do not act now to reduce the magnitude of climate change, the price to pay would approximate 5 to $20 \%$ of the global GDP each year. In contrast, reducing greenhouse gas emissions to avoid the worst consequences of climate change would cost only $1 \%$ of the global GDP per year. Second, current evidence suggests that investments in AT-related infrastructure are highly cost-effective (Cavill et al., 2008; Gotschi, 2011). Therefore, by attacking several of today's most important environmental and health problems, AT is a powerful strategy that should not be overlooked by policy-makers. Hence, "Levels of cycling can be seen as a measure of progress towards a healthier sustainable future in both the developed and the developing world" (Woodcock et al., 2007).

\section{Acknowledgements}

Richard Larouche is a member of the Healthy Active Living and Obesity Research Group at the Children's Hospital of Eastern Ontario and a doctoral student at the University of Ottawa. He holds a Frederick Banting and Charles Best Canada Graduate Scholarship from the Canadian Institutes of Health Research. Publication of this book chapter was supported by the University of Ottawa Author Fund.

\section{References}

Andersen, L.B., Schnohr, P., Schroll, M. \& Hein, H.O. (2000). All-cause mortality associated with physical activity during leisure time, work, sports, and cycling to work Archives of Internal Medicine, Vol.160, No.11 (June 2000), pp. 1621-1628, ISSN 00039926

Andersen, L.B., Wedderkopp, N., Kristensen, P., Moller, N.C., Froberg, K. \& Cooper, A.R. (2011). Cycling to school and cardiovascular risk factors: a longitudinal study. Journal of Physical Activity and Health, Vol.8, No. (November 2011), pp. 1025-1033. ISSN 1543-3080

Appleyard, B. (2003). Planning Safe Routes to School. Planning, Vol.69, No.5 (May 2003), pp.34-37. ISSN 0001-2610

Ball, K., Timperio, A., Salmon, J., Giles-Corti, B., Roberts, R. \& Crawford, D. (2007). Personal, social and environmental determinants of educational inequalities in walking. Journal of Epidemiology and Community Health, Vol.61, No.2 (February 2007), pp. 108114. ISSN 0143-005X 
Bandura, A. (1986) Social foundations of thought and action: a social cognitive theory. Englewoods Cliff, New Jersey: Prentice Hall. ISBN 013815614X

Banister, D (2008). The sustainable mobility paradigm. Transport Policy, Vol.15, No.2 (March 2008), pp. 73-80, ISSN 0967-070X

Bauman, A., Sallis, J. F., Dzewaltowski, D. A. \& Owen, N. (2002). Toward a better understanding of the influences on physical activity: the role of determinants, correlates, causal variables, mediators, moderators, and confounders. American Journal of Preventive Medicine, Vol.23 No.2 (August 2002), pp. S5-S14, ISSN 07493797

Bell, C., Garrard, J., \& Swinburn, B. (2006). Active transport to work in Australia: is it all downhill from here? Asia Pacific Journal of Public Health, Vol.18, No.1 (March 2006), pp. 62-68, ISSN 1010-5395

Bopp, M., Kaczynski, A.T., \& Wittman, P. (2011). The relationship of eco-friendly attitudes with walking and biking to work. Journal of Public Health Management and Practice, Vol.17, No.5 (September/October 2011), pp. E9-E17, ISSN 1078-4659

Bronfenbrenner, U. (1979). The ecology of human development: Experiments by nature and design. Cambridge, Mass: Harvard University Press. ISBN 0674224566.

Brook, R.D., Rajagopalan, S., Pope III, A., Brook, J.R., Bhatnagar, A. et al. (2010). Particulate matter air pollution and cardiovascular disease: an update to the scientific statement from the American Heart Association. Circulation, Vol.121 (June 2010), pp. 2331-2378, ISSN 0009-7322

Brunekreef, B., \& Holgate, S.T. (2002). Air pollution and health. Lancet, Vol.360, No.9341 (October 2002), pp. 1233-1242, ISSN 0140-6736

Buliung, R.N., Mitra, R., \& Faulkner, G. (2009). Active school transportation in the Greater Toronto Area, Canada: An exploration of trends in space and time (1986-2006). Preventive Medicine, Vol.48, No.6 (June 2009), pp. 507-512, ISSN 0091-7435

Cavill, N., Kahlmeier, S., Rutter, H., Racioppi, F. \& Oja, P. (2008). Economic analyses of transport infrastructure and policies including health effects related to cycling and walking: A systematic review. Transport Policy, Vol.15, No.5 (September, 2008), pp. 291-304, ISSN 0967-070X

Cervero, R. \& Kockelman, K. (1997). Travel demands and the 3Ds: Density, diversity and design. Transportation Research Part D: Transport and Environment, Vol.2, No.3 (September 1997), pp. 199-219, ISSN 1361-9209

Chapman, L. (2007). Transport and climate change: A review. Journal of Transport Geography, Vol.15, No.5 (September 2007), pp. 354-367, ISSN 0966-6923

Chillón, P., Evenson, K.R., Vaughn, A. \& Ward, D.S. (2011). A systematic review of interventions for promoting active transportation to school. International Journal of Behavioral Nutrition and Physical Activity, Vol.8, No.10, ISSN 1479-5868 http://www.ijbnpa.org/content/pdf/1479-5868-8-10.pdf

Colley, R.C, Garriguet, D., Janssen, I., Craig, C.L., Clarke, J. \& Tremblay, M.S. (2011). Physical activity of Canadian children and youth: Accelerometer results from the 2007 to 2009 Canadian Health Measures Survey. Health Reports, Vol.22, No.1 (March 2011), pp. 15-23, ISSN 0840-6529

Colley, R.C, Garriguet, D., Janssen, I., Craig, C.L., Clarke, J. \& Tremblay, M.S. (2011). Physical activity of Canadian adults: Accelerometer results from the 2007 to 2009 
Canadian Health Measures Survey. Health Reports, Vol.22, No.1 (March 2011), pp. 714, ISSN 0840-6529

Cooper, A.R., Wedderkopp, N., Jago, R., Kristensen, P.L., Moller, N.C., et al. (2008). Longitudinal associations of cycling to school with adolescent fitness. Preventive Medicine, Vol.48, No.3 (September 2008), pp. 324-328, ISSN 0091-7435

Davison, K.K., Werder, J.L, \& Lawson, C.T. (2008). Children's active commuting to school: current knowledge and future directions. Preventing Chronic Diseases, Vol.5, No.3 (July 2008), pp. 1-11, ISSN 1545-1151

de Geus, B., de Bourdeaudhuij, I., Jannes, C., \& Meeusen, R. (2008). Psychosocial and environmental factors associated with cycling for transport among a working population. Health Education Research, Vol.23, No.4 (August 2008), pp. 697-708, ISSN 0268-1153

de Geus, B., Joncheere, J., \& Meeusen, R. (2009).Commuter cycling: effect on physical performance in untrained men and women in Flanders: minimum dose to improve indexes of fitness. Scandinavian Journal of Medicine E Science in Sports, Vol. 19, No.2 (April 2009), 179-187, ISSN 1600-838

de Hartog, J.J., Boogaard, H., Nijland, H. \& Hoek, G. (2010). Do the health benefits of cycling outweigh the risks? Environmental Health Perspectives, Vol.118, No.8 (August 2010), pp. 1109-1116, ISSN 0091-6765

de Nazelle, A., Morton, B.J., Jerret, M., \& Crawford-Brown, D. (2010). Short trips: an opportunity for reducing mobile-source emissions? Transportation Research Part D, Vol.15, No.8 (December 2010), pp.451-457, ISSN 1361-9209

de Nazelle, A., Nieuwenhuijsen, M.J., Anto, J.M., Brauer, M., Briggs, D., et al. (2011). Improving health through policies that promote active travel: A review of evidence to support health impact assessment. Environment International, Vol.37, No.4 (May 2011), pp. 766-777, ISSN 0160-4120

DeMaio, P. (2009). Bike-sharing: History, impacts, models of provision and future. Journal of Public Transport, Vol.12, No.4, pp. 41-56, ISSN 1077-291X

Demers, M., (2008) Pour une ville qui marche: Aménagement urbain et santé. Montréal, Québec : Écosociété ISBN 978-2-923165-35-6

Dill, J., \& Carr, T. (2003). Bicycle commuting and facilities in major U.S. cities: if you build them, commuters will use them. Transportation Research Record, Vol.1828 (January, 2003), pp. 116-123, ISSN 0361-1981

Dunn, A.L., Marcus, B.H., Kampert, J.B., Garcia, M.E., Kohl III, H.W. \& Blair, S.N. (1999). Comparison of lifestyle and structured interventions to increase physical activity and cardiorespiratory fitness: a randomized controlled trial. Journal of the American Medical Association, Vol.281, No.4 (January 1999), 327-334. ISSN 1538-3598

Elvik, R. (2009). The non-linearity of risk and the promotion of environmentally sustainable transport. Accident Analysis \& Prevention, Vol.41, No.4 (July 2009), pp. 849-855, ISSN 0001-4575

Ewing, R., Schmid, T., Killingsworth, R., Zlot, A., \& Raudenbush, S. (2003). Relationship between urban sprawl and physical activity, obesity and morbidity. American Journal of Health Promotion, Vol.18, No.1 (January 2003), pp. 47-57 ISSN 0890-1171

Faulkner, G.E.J., Buliung, R.N., Flora, P.K. \& Fusco, C. (2009). Active school transport, physical activity levels and body weight of children and youth: A systematic Review. Preventive Medicine, Vol.48, No.1 (January 2009), pp. 3-8, ISSN 0091-7435 
Faulkner, G.E.J., Richichi, V., Buliung, R.N., Fusco, C., \& Moola, F. (2010). What's “quickest and easiest"?: parental decision making about school trip mode. International Journal of Behavioral Nutrition and Physical Activity, Vol.7, No.62, ISSN 1479-5868. http://www.biomedcentral.com/content/pdf/1479-5868-7-62.pdf

Franco, M., Ordunez, P., Caballero, B., \& Cooper, R.S. (2008). Obesity reduction and its possible consequences: what can we learn from Cuba's special period? Canadian Medical Association Journal, Vol.178, No.8 (April 2008), pp.1032-1034, ISSN 0820-3946

Frank, L.D., Stone, B.J., \& Bachman, W. (2000). Linking land use with household vehicle emissions in the central Puget Sound: Methodological framework and findings. Transportation Research Part D, Vol.5, No.3 (May 2000), pp. 173-190, ISSN 1361-9209

Frank, L.D., Sallis, J.F., Conway, T.L., Chapman, J.E., Saelens, B.E. \& Bachman, W. (2006). Many pathways from land use to health - associations between neighborhood walkability and active transportation, body mass index, and air quality. Journal of the American Planning Association, Vol.72, No.1 (Winter 2006), pp. 75-87. ISSN 01944363

Frank, L.D., Saelens, B.E., Powell, K.E. \& Chapman, J.E. (2007). Stepping towards causation: do built environments or neighborhood and travel preferences explain physical activity, driving, and obesity? Social Science \& Medicine, Vol.65, No.9 (November 2007), pp.1898-1914. ISSN 0277-9536

Frank, L.D., Greenwald, M.J., Winkelman, S., Chapman, J. \& Kavage, S. (2010). Carbonless footprints: promoting health and climate stabilization through active transportation. Preventive Medicine, Vol.50, No.1 (Suppl.) (January 2010), pp.99-105, ISSN 0091-7435

Friedenreich, C. M., \& Orenstein, M. R. (2002). Physical activity and cancer prevention: Etiologic evidence and biological mechanisms. Journal of Nutrition, Vol.132, No.11 (November 2002), pp. 3456S-3364S, ISSN 0022-3166

Friedman, M.S., Powell, K.E., Hutwagner, L., Graham, L.M. \& Teague, W.G. (2001). Impact of changes in transportation and commuting behaviors during the 1996 Summer Olympic Games in Atlanta on air quality and childhood asthma. Journal of the American Medical Association, Vol.285, No.7 (July 2001), pp. 897-905. ISSN 0098-7484

Frumkin, H., Frank, L. \& Jackson, R. Urban sprawl and public health: Designing, planning, and building for healthy communities. Washington, DC: Island Press. ISBN 1-55963-305-0

Garrard, J., Rose, G., Lo, S.J. (2008). Promoting transportation cycling for women: the role of bicycle infrastructure. Preventive Medicine, Vol.46, No.1 (January 2008), pp.55-59, ISSN 0091-7435

Giles-Corti, B. (2006). People or places: what should be the target? Journal of Science and Medicine in Sports, Vol.9, No.5 (October 2006), pp. 357-366, ISSN 1440-2440

Gordon-Larsen, P., Boone-Heinonen, J., Sidney, S., Sternfeld, B., Jacobs, D.R. Jr. \& Lewis, C.E. (2009). Active commuting and cardiovascular disease risk: The CARDIA study. Archives of Internal Medicine, Vol.169, No.13 (July 2009), pp. 1216-1223, ISSN 0003-9926

Gotschi, T. (2009). Costs and benefits of bicycling investments in Portland, Oregon. Journal of Physical Activity and Health, Vol.8, No.1 (Suppl.) (January 2010), pp. S49-S58, ISSN 1543-3080

Grize, L., Bringolf-Isler, B., Martin, E., Braun-Fahrländer, C. (2010). Trends in active transport to school among Swiss school children and its associated factors: three 
cross-sectional surveys 1994, 2000 and 2005. International Journal of Behavioral Nutrition and Physical Activity, Vol.7, No.28, ISSN 1479-5868. http://www.ijbnpa.org/content/7/1/28.

Haines, A., McMichael, A.J., Smith, K.R., Roberts, I., Woodcock, J. et al. (2010). Public health benefits of strategies to reduce greenhouse-gas emissions: Overview and implications for policy makers. Lancet, Vol.374, No.9707 (January 2010), pp. 21042114, ISSN 0140-6736

Hamer, M. \& Chida, Y. (2008). Active commuting and cardiovascular risk: a meta-analytic review. Preventive Medicine, Vol.46, No.1 (January 2008), pp. S9-S13, ISSN 0091-7435

Handy, S.L., Cao, X. \& Mokhtarian, P.L. (2005). Correlation or causality between the built environment and travel behavior? Evidence from Northern California. Transportation Research Part D, Vol.10, No.6 (November 2005), pp. 427-444, ISSN 1361-9209.

Handy, S.L., Cao, X., \& Mokhtarian, P.L. (2006). Self-selection in the relationship between the built environment and walking. Journal of the American Planning Association, Vol.72, No.1 (Winter 2006), pp.55-74. ISSN 0194-4363

Hanlon, P., \& McCartney, G. (2008). Peak oil: will it be public health's greatest challenge. Public Health, Vol.122, No.7 (July 2008), pp. 647-652, ISSN 0033-3506

Harris, K.C., Kuramoto, L.K., Schulzer, M, \& Retallack, J.E. (2009). Effect of school-based physical activity interventions on body mass index in children: a meta-analysis. Canadian Medical Association Journal, Vol.180, No.7 (July 2008), pp. 719-726, ISSN 0820-3946

Heelan, K.A., Abbey, B.M., Donnely, JE., Mayo, M.S. \& Welk, G.J. (2009). Evaluation of a walking school bus for promoting physical activity in youth. Journal of Physical Activity and Health, Vol.6, No.5 (September 2009), pp. 560-567, ISSN 1543-3080

Hendriksen, I.J.M., Zuiderveld, B., Kemper, H.C.G. \& Bezemer, P.D. (2000). Effect of commuter cycling on physical performance of male and female employees. Medicine E Science in Sports and Exercise, Vol.32, No.2 (February 2000), pp. 504-510. ISSN 0195-9131

Hinckson, E.A. \& Badland, H.M. (2011). School travel plans: Preliminary evidence for changing school-related travel patterns in elementary school children. American Journal of Health Promotion, Vol.25, No.6 (July 2011), pp.368-371, ISSN 0890-1171

Horton, R. (2007). Righting the balance: energy for health. Lancet, Vol.370, No.9591 (September 2007), pp. 921, ISSN 0140-6736

$\mathrm{Hu}$, G., Sarti, C., Jousilahti, P., Silventoinen, K., Barengo, N.C. \& Tuomilehto, J. (2005). Leisure time, occupational, and commuting physical activity and the risk of stroke. Stroke, Vol.36, No.9 (September 2005), pp. 1994-1999, ISSN 0039-2499

$\mathrm{Hu}$, G., Jousilahti, P., Borodulin, K., Barengo, N.C., Lakka, T.A., Nissinen, A. \& Tuomilehto, J. (2007). Leisure time, occupational, and commuting physical activity in relation to coronary heart disease among middle-aged Finnish men and women. Atherosclerosis, Vol.194, No.2 (October 2007), pp. 490-497, ISSN 0021-9150

Hume, C., Timperio, A., Salmon, J., Carver, A., Giles-Corti, B. \& Crawford, D. (2009). Walking and cycling to school: Predictors of increase among children and adolescents. American Journal of Preventive Medicine, Vol.36, No.3 (March 2009), pp. 195-200, ISSN 0749-3797 
Humpel, N., Owen, N, Iverson, D., Leslie, E. \& Bauman, A. (2004). Perceived environmental attributes, residential location, and walking for particular purposes. American Journal of Preventive Medicine, Vol.26, No.2 (February 2004), pp. 119-125, ISSN 07493797

Jacobs, J. (1961). The death and life of great American cities. New York: Random House. ISBN 9780679741954

Jacobson, P.L. (2003). Safety in numbers: more walkers and bicyclists, safer walking and bicycling. Injury Prevention, Vol.9, No.3 (September 2003), pp. 205-209, ISSN 13538047

Jéquier, E. \& Tappy, L. (1999). Regulation of body weight in humans. Physiological Reviews, Vol.79, No.2 (April 1999), pp. 451-480, ISSN 0031-9333

Johanssen, C., Burman, L. \& Forsberg, B. (2009). The effects of congestions tax on air quality and health. Atmospheric Environment, Vol.43, No.31 (October 2009), pp. 4843-4854, ISSN 1352-2310

Kaza, N., Knaap, G.J., Knaap, I., \& Lewis, R. (2011). Peak oil, urban form, and public health: exploring the connections. American Journal of Public Health, Vol.101, No.9 (September 2011), pp.1598-1606, ISSN 1541-0048

Keith, S.W., Redden, D.T., Katzmarzyk, P.T., Boggiano, M.M., Hanlon, E.C. et al. (2006). Putative contributors to the secular increase in obesity: exploring the roads less travelled. International Journal of Obesity, Vol.30, No.11 (June 2006), pp. 1585-1594, ISSN 0307-0365

King, A.C., Stokols, D., Tahen, E., Brassington, G.S. \& Killingsworth, R. (2002). Theoretical approaches to the promotion of physical activity: forging a transdisciplinary paradigm. American Journal of Preventive Medicine, Vol.22, No.2 (February 2002), pp. S15-S25, ISSN 0749-3797

International Transport Forum (2010). Reducing transport greenhouse gas emissions: Trends and data 2010. Leipzig, Germany. http:/ / www.internationaltransportforum.org/Pub/pdf/10GHGTrends.pdf

Larouche, R. \& Trudeau, F. (2010). Étude des impacts du transport actif sur la pratique d'activités physiques et la santé et de ses principaux déterminants. Science $\mathcal{E}$ Sports, Vol.25, No.5 (November 2010), pp. 227-237. ISSN 0765-1597

Larouche, R., Saunders, T.J., Faulkner, G.E.J., Colley, R.C. \& Tremblay, M.S. (submitted). Associations between active school transport and physical activity, body composition and cardiovascular fitness: a systematic review of 57 studies. Journal of Physical Activity and Health. ISSN 1543-3080

Lemieux, M., \& Godin, G. (2009). How well do cognitive and environment variables predict active commuting? International Journal of Behavioral Nutrition and Physical Activity, Vol.6, No.12, ISSN 1479-5868 http://www.biomedcentral.com/content/pdf/14795868-6-12.pdf

Levy, J.I., Buonocore, J.J., \& von Stackelberg, K. (2010). Evaluation of the public health impacts of traffic congestion: A health risk assessment. Environmental Health, Vol.9, No.65, ISSN 1476-069X http:/ / www.ehjournal.net/content/9/1/65

Lobstein, T., Baur L. \& Uauy, R. (2004). Obesity in children and young people: a crisis in public health. Obesity Reviews, Vol.5 No.1 Suppl. (May 2004), 4-85, ISSN 1467-7881

Manson, J.E., Greenland, P.E., LaCroix, A.Z., Stefanick, M.L., Mouton, C.P., et al. (2002). Walking compared with vigorous exercise for the prevention of cardiovascular 
events in women. New England Journal of Medicine, Vol.347, No.10 (September 2002), pp. 716-725. ISSN 0028-4793

Mapes, J. (2009). Pedaling revolution: how cyclists are changing American cities. Corvallis, OR: Oregon State University Press, ISBN 978-0-87071-419-1

Marshall, J.D., Brauer, M. \& Frank, L.D. (2009). Healthy neighborhoods: walkability and air pollution. Environmental Health Perspectives, Vol.117, No.11 (November 2009), pp.1752-1759, ISSN 0091-6765

Marshall, J.D., Wilson, R.D., Meyer, K.L., Rajangam, S.K., McDonald, N.C. \& Wilson, E.J. (2010). Vehicle emissions during children's school commuting: Impact of education policy. Environmental Science E Technology, Vol.44, No.5 (January 2010), pp. 15371543, ISSN 0013-936X

Matthews, C.E., Juri, A.L., Shu, X.O., Li, H.L., Yang, G., Li, Q., Gao, Y.T. \& Zheng, W. (2007). Influence f exercise, walking, cycling, and overall nonexercise physical activity on mortality in Chinese women. American Journal of Epidemiology, Vol.165, No.12 (June 2007), pp.1343-1350, ISSN 0002-9262

McDonald, N.C. (2007). Active transportation to school: Trends among U.S. schoolchildren, 1969-2001. American Journal of Preventive Medicine, Vol.32, No.6 (June 2007), pp. 509516, ISSN 0749-3797

McLeroy, K.R., Bibeau, D., Steckler, A. \& Glanz, K. (1988). An ecological perspective on health promotion programs. Health Education Quarterly, Vol.15, No.4 (Winter 1988), pp. 351-377, ISSN 0195-8402

McMichael, A.J., Butler, C.D. (2011). Promoting global population health while constraining the environmental footprint. Annual Reviews of Public Health, Vol.32, (April 2011), pp. 179-197, ISSN 0136-9529

McMillan, T.E. (2005). Urban form and a child's trip to school: The current literature and a framework for future research. Journal of Planning Literature, Vol.19, No.4 (May 2005), pp. 440-456, ISSN 0885-4122

Morency, P. \& Demers, M. (2009). Active transportation as a way to increase physical activity among children. Child: Care, Health and Development, Vol. 36, No.3 (May 2010), pp. 421-427, ISSN 1365-2214

Muniz, I., \& Galindo, A. (2005). Urban form and the ecological footprint of commuting. The case of Barcelona. Ecological Economics, Vol.55, No.4 (December 2005), pp. 499-514, ISSN 0921-8009

Ogilvie, D., Egan, M., Hamilton, V. \& Petticrew, M. (2004). Promoting walking and cycling as an alternative to using cars: systematic review. British Medical Journal, Vol.329, No.7469 (October 2004), pp.763-766, ISSN 0959-8146

Ogilvie, D., Mitchell, R., Mutrie, N., Petticrew, M., \& Platt, S. (2008). Personal and environmental correlates of active travel and physical activity in a deprived urban population. International Journal of Behavioral Nutrition and Physical Activity, Vol.5, No.43, ISSN 1479-5868 http:/ / www.ijbnpa.org/content/5/1/43

Oja, P., Mänttäri, A., Heinonen, A., Kukkonen-Harjula, K., Laukanen, R., Pasanen, M. \& Vuori, I. (1991). Physiological effects of walking and cycling to work. Scandinavian Journal of Medicine $\mathcal{E}$ Science in Sports, Vol.1, No.3 (September 1991), pp. 151-157, ISSN 1600-838 
Oja, P. \& Vuori, I., \& Paronen, O. (1998). Daily walking and cycling to work: their utility as health enhancing physical activity. Patient Education and Counselling, Vol.33, No.1 (April 1998), pp. S87-S94, ISSN 0738-3991

Oja, P. \& Vuori, I. (2000). Promotion of transport walking and cycling in Europe: strategy directions. Tampere, Finland: UKK Institute for Health Promotion Research. http://www.panh.ch/hepaeurope/materials/HEPA\%20Walking\%20and\%20Cycli ng\%20Strategy \%20.pdf

Oja, P., Titze, S., Bauman, A., de Geus, A., Krenn, P., Reger-Nash, B., \& Kohlberger, T. (2011). Health benefits of cycling: Systematic review. Scandinavian Journal of Medicine E Science in Sports, Vol.21, No.4 (August 2011), pp.496-509, ISSN 1600-838

Owen, N., Humpel, N., Leslie, E., Bauman, A. \& Sallis, J.F. (2004). Understanding environmental influences on walking: Review and research agenda. American Journal of Preventive Medicine, Vol.27, No.1 (July 2004), pp. 67-76, ISSN 0749-3797

Paffenbarger, R.S. Jr., Hyde, R.T., Wing, A.L., Lee, I., Jung, D.L. \& Kampert, J.B. (1993). The association of changes in physical activity level and other lifestyle characteristics with mortality among men. New England Journal of Medicine, Vol.328, No.8 (February 1993), pp.538-545, ISSN 0028-4793

Pabayo, R. \& Gauvin, L. (2008). Proportion of students who use various modes of transportation to and from school in a representative population-based sample of children and adolescents, 1999. Preventive Medicine, Vol.46, No.1 (January 2008), pp. 63-66, ISSN 0091-7435

Pabayo, R., Gauvin, L. \& Barnett, T.A. (2011). Longitudinal changes in active transportation to school in Canadian youth aged 6 through 16 years. Pediatrics, Epub 2011 Jul 4. ISSN 0031-4005

Panter, J.R., Jones, A.P., van Sluijs \& E.M.F. (2008). Environmental determinants of active travel in youth: A review and framework for future research. International Journal of Behavioral Nutrition and Physical Activity, Vol.5, No.34, ISSN 1479-5868 http://www.ijbnpa.org/content/5/1/34/

Panter, J.R., Jones, A.P., van Sluijs, E.M.F. \& Griffin, S.J. (2011). The influence of distance to school on the association between active commuting and physical activity. Pediatric Exercise Science, Vol.23, No.1 (March 2011), pp. 72-86, ISSN 1541-0048

Pucher, J. \& Buehler, R. (2008). Making cycling irresistible: Lessons from The Netherlands, Denmark and Germany. Transport Reviews, Vol.28, No.4 (July 2008), pp. 495-528, ISSN 0899-8493

Pucher, J., Dill, J. \& Handy, S. (2010). Infrastructures, programs and policies to increase bicycling: an international review. Preventive Medicine, Vol.50, No.1 (January 2010), pp. S106-S125, ISSN 0091-7435

Pucher, J., Buehler, R., Bassett, D.R. Jr. \& Dannenberg, A.L. (2010). Walking and cycling to health: A comparison of recent evidence from cities, states, and international studies. American Journal of Public Health. Vol.100, No.10 (October 2010), pp. 19861992, ISSN 1541-0048

Rojas-Rueda, D., de Nazelle, A., Tainio, M. \& Nieuwenhuijsen, M.J. (2011). The health risks and benefits of cycling in urban environments compared with car use: health impact assessment study. British Medical Journal. Epub ahead of print, August 4, 2011, ISSN 0959-8138 
Saelens, B.E., Sallis, J.F., Black, J.B., \& Chen, D. (2003). Neighborhood-based differences in physical activity: an environment scale evaluation. American Journal of Public Health, Vol.93, No.9 (September 2003), pp. 1552-1558, ISSN 1541-0048

Saelens, B.E. \& Handy, S.L. (2008). Built environment correlates of walking: A review. Medicine and Science in Sports E Exercise, Vol.40, No.7 (Supplement 7) (July 2008), pp. S550-S566, ISSN 0195-9131

Sallis, J.F., Cervero, R.B., Ascher, W., Henderson, K.A., Kraft, M.K. \& Kerr, J. (2006). An ecological approach to creating active living communities. Annual Reviews of Public Health, Vol.27, (April 2006), pp. 297-322, ISSN 0163-7525

Shannon, T., Giles-Corti, B., Pikora, T., Bulsara, M., Shilton, T., \& Bull, F. (2006). Active commuting in a university setting: assessing commuting habits and potential for modal change. Transport Policy, Vol.13, No.3 (May 2006), pp. 240-253, ISSN 0967070X

Sigal, R.J., Kenny, G.P., Wasserman, D.H., Castaneda-Sceppa, D. \& White, R.D. (2006). Physical activity / Exercise and type 2 diabetes: A consensus statement from the American Diabetes Association. Diabetes Care, Vol.29, No.6 (June 2006), pp. 14331438, ISSN 0149-5992

Stern, N. (2006). Stern review on the economics of climate change. London: HM Treasury. http://mudancasclimaticas.cptec.inpe.br/ rmclima/pdfs/destaques/sternreview _report_complete.pdf

Stokols, D. (1996). Translating social ecological theory into guidelines for community health promotion. American Journal of Health Promotion, Vol.10, No.4 (March-April 1996), pp. 282-298, ISSN 0890-1171

Tin Tin, S., Woodward, A., Thornley, S. \& Ameratunga, S. (2011). Regional variations in pedal cyclist injuries in New Zealand: safety in numbers or risk in scarcity? Australian and New Zealand Journal of Public Health, Vol.35, No.4 (August 2011), pp.357-363. ISSN 1753-6405

Titze, S., Stronneger, W.J., Janschitz, S., \& Oja, P. (2007). Environmental, social and personal correlates of cycling for transportation in a student population. Journal of Physical Activity and Health, Vol.4, No.1 (January 2007), pp. 66-79, ISSN 1543-3080

Titze, S., Stronneger, W.J., Janschitz, S., \& Oja, P. (2008). Association of built-environment, social-environment and personal factors with bicycling as a mode of transportation among Austrian city dwellers. Preventive Medicine, Vol.47, No.3 (September 2008), pp. 252-259, ISSN 0091-7435

Tonne, C., Beevers, S., Armstrong, B., Kelly, F. \& Wilkinson, P. (2008). Air pollution and mortality benefits of the London Congestion Charge: spatial and socioeconomic inequalities. Occupational Environmental Medicine, Vol.65, No.9 (September 2008), pp. 620-627, ISSN 1470-7926

Troiano, R.P., Berrigan, D., Dodd, K.W., Mâsse, L.C., Tilert, T. \& McDowell, M. (2008). Physical activity in the United States measured by accelerometers. Medicine $\mathcal{E}$ Science in Sports \& Exercise. Vol.40, No.1 (January 2008), pp. 181-188, ISSN 0195-9131

Troped, P., Saunders, R.P., Pate, R.R., Reininger, B., \& Addy, C.L. (2003). Correlates of recreational and transportation physical activity among adults in a New England community. Preventive Medicine, Vol.37, No.4 (October 2003), pp.304-310, ISSN 0091-7435 
Turcotte, M. (2008). Dépendance à l'automobile dans les quartiers urbains. Tendances Sociales Canadiennes, Vol.1, No.1, p.21-32, ISSN 1481-1642 http://www.statcan.gc.ca/pub/11-008-x/2008001/article/10503-fra.pdf

Unger, N., Bond, T.C., Wang, J.S., Koch, D.M., Menon, S. et al. (2010). Attribution of climate forcing to economic sectors. Proceedings of the National Academy of Science, Vol.107, No.8 (February 2010), pp. 3382-3387, ISSN 1091-6490

US Environmental Protection Agency. (1999). The transportation and environmental impacts of infill vs. greenfield development: a comparative case study analysis. Washington, DC: Urban and Economic Development Division, U.S. Environmental Protection Agency. http://www.epa.gov/smartgrowth/pdf/infill_greenfield.pdf

van der Ploeg, H.P., Merom, D., Corpuz, G., \& Bauman, A.E. (2008). Trends in Australian children travelling to school 1971-2003: Burning petrol or carbohydrates? Preventive Medicine, Vol.46, No.1 (January 2008), pp. S60-S62, ISSN 0091-7435

van Sluijs, E.M.F., Fearne, V.A., Mattocks, C., Riddoch, C., Griffin, S.J., Ness, A. (2009). The contribution of active travel to children's physical activity levels: Cross-sectional results from the ALSPAC study. Preventive Medicine, Vol.48, No.6 (June 2009), pp. 519-524, ISSN 0091-7435

Wang, Y., Hao, J., McElroy, M.B., Munger, J.W., Ma, H., Chen, D., Nielsen, C. P. (2009). Ozone air quality during the 2008 Beijing Olympics: effectiveness of emission restrictions. Atmospheric Chemistry and Physics, Vol.9, No.3 (January 2007), pp.52375251, ISSN 1352-2310

Wang, Y. \& Lobstein, T. (2006). Worldwide trends in childhood overweight and obesity. International Journal of Pediatric Obesity, Vol.1, No.1, pp. 11-25, ISSN 1747-7166

Weiss, H. \& Bradley, R.S. (2001). What drives societal collapse? Science, Vol.291, No.5504 (January 2001), pp.609-610, ISSN 0036-8075

Wen, L.M. \& Rissel, C. (2008). Inverse associations between cycling to work, public transport, and overweight and obesity: findings from a population based study in Australia. Preventive Medicine, Vol.46, No.1 (January 2008), pp.29-32, ISSN 00917435

Wen, L.M., Kite, J., \& Rissel, C. (2010). Is there a role for workplaces for reducing employees' driving to work? Findings from a cross-sectional survey from inner-west Sydney, Australia. BMC Public Health, Vol.10, No.50, ISSN 1471-2458 http://www.biomedcentral.com/content/pdf/1471-2458-10-50.pdf

Wennberg, P., Wensley, F., Johansson, L., Boman, K., Di Angelantonio, E., et al. (2010). Reduced risk of myocardial infarction related to active commuting: inflammatory and haemostatic effects are potential major mediating mechanisms. European Journal of Cardiovascular Prevention and Rehabilitation, Vol.17, No. 1 (February 2010), pp.56-62, ISSN 1741-8267

Woodcock, J., Banister, D., Edwards, P., Prentice, A.M. \& Roberts, I. (2007). Energy and transport. Lancet, Vol.370 No.9592 (September 2007), pp. 1078-1088, ISSN 0140-6736

Woodcock, J., Edwards, P., Tonne, C., Armstrong, B.G., Ashiru, O. et al. (2009). Public health benefits of strategies to reduce greenhouse-gas emissions: urban land transport. Lancet, Vol.374, No.9705, pp.1930-1943 (December 2009), ISSN 0140-6736

Wong, B.Y.M., Faulkner, G. \& Buliung, R. (2011). GIS measured environmental correlates of active school transport: A systematic review of 14 studies. International Journal of 
Behavioral Nutrition and Physical Activity, Vol.8, No.39, ISSN 1479-5868 http://www.ijbnpa.org/content/pdf/1479-5868-8-39.pdf

Yang, L., Sahlqvist, S., McMinn, A., Griffin, S.J. \& Ogilvie, D. (2010) Interventions to promote cycling: systematic review. British Medical Journal, Vol.341, No.5293 (October 2010), ISSN 0959-8146

Younger, M., Morrow-Almeida, H.R., Vindigni, S.M., \& Dannenberg, A.L. (2008). The built environment, climate change, and health: opportunities for co-benefits. American Journal of Preventive Medicine, Vol.35, No.5 (November 2008), 517-526, ISSN 07493797

Zhou, W. \& Szyliowicz, J.S. (2006). The development and current status of China's transportation system. World Transport Policy \& Practice, Vol.12 No.4 (Setember 2006), pp. 10-16, ISSN 1352-7614 


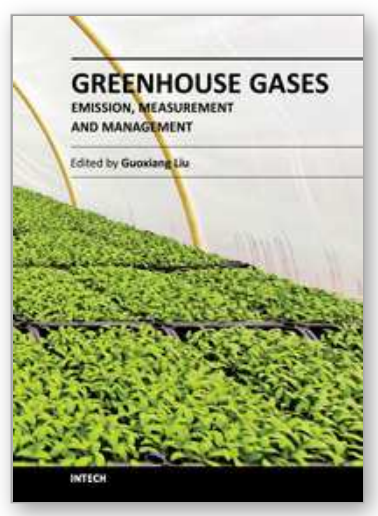

\section{Greenhouse Gases - Emission, Measurement and Management \\ Edited by Dr Guoxiang Liu}

ISBN 978-953-51-0323-3

Hard cover, 504 pages

Publisher InTech

Published online 14, March, 2012

Published in print edition March, 2012

Understanding greenhouse gas sources, emissions, measurements, and management is essential for capture, utilization, reduction, and storage of greenhouse gas, which plays a crucial role in issues such as global warming and climate change. Taking advantage of the authors' experience in greenhouse gases, this book discusses an overview of recently developed techniques, methods, and strategies: - A comprehensive source investigation of greenhouse gases that are emitted from hydrocarbon reservoirs, vehicle transportation, agricultural landscapes, farms, non-cattle confined buildings, and so on. - Recently developed detection and measurement techniques and methods such as photoacoustic spectroscopy, landfill-based carbon dioxide and methane measurement, and miniaturized mass spectrometer.

\section{How to reference}

In order to correctly reference this scholarly work, feel free to copy and paste the following:

Richard Larouche (2012). The Environmental and Population Health Benefits of Active Transport: A Review, Greenhouse Gases - Emission, Measurement and Management, Dr Guoxiang Liu (Ed.), ISBN: 978-953-510323-3, InTech, Available from: http://www.intechopen.com/books/greenhouse-gases-emission-measurementand-management/the-environmental-and-population-health-benefits-of-active-transport-a-review

\section{INTECH}

open science | open minds

\section{InTech Europe}

University Campus STeP Ri Slavka Krautzeka 83/A 51000 Rijeka, Croatia Phone: +385 (51) 770447 Fax: +385 (51) 686166 www.intechopen.com

\section{InTech China}

Unit 405, Office Block, Hotel Equatorial Shanghai No.65, Yan An Road (West), Shanghai, 200040, China 中国上海市延安西路65号上海国际贵都大饭店办公楼 405 单元 Phone: +86-21-62489820

Fax: $+86-21-62489821$ 
(C) 2012 The Author(s). Licensee IntechOpen. This is an open access article distributed under the terms of the Creative Commons Attribution 3.0 License, which permits unrestricted use, distribution, and reproduction in any medium, provided the original work is properly cited. 